\title{
MANAJEMEN PENDIDIKAN KARAKTER PADA PONDOK PESANTREN AN NAWAWI BERJAN PURWOREJO
}

\author{
Muhlil Musolin \\ STAI An Nawawi Purworejo \\ e-mail: mmuhlil@yahoo.com
}

\begin{abstract}
Islamic boarding schools are Islamic education institutions that are increasingly in demand because in addition to making smart students but also forming the character of students to be positive characters, especially salaf Islamic boarding schools. An Nawawi Islamic boarding school is one of the salaf Islamic boarding schools in Purworejo district which is increasingly in demand with the increasing number of santri and now reaching 3500 santri. This study wanted to know how the management process of character education at An Nawawi Islamic Boarding School. An Nawawi Islamic Boarding School succeeded in organizing character education with elements of supporting elements, namely the independence of pesantren leadership, Islamic boarding school regulations and good management management
\end{abstract}

\section{ABSTRAK}

Pesantren merupakan lembaga pendidikan Islam yang semakin hari semakin diminati karena selain membuat peserta didik cerdik namun juga membentuk karakter peserta didik menjadi karakter yang positif terutama pondok pesantren salaf.Pondok pesantren An Nawawi adalah salah satu pondok pesantren salaf di kabupaten Purworejo yang semakin hari semakin diminati dengan jumlah santri yang semakin meningkat dan sekarang ini mencapai 3500 orang santri.Penelitian ini ingin mengetahui bagaimana proses manajemen pendidikan karakter di Pondok Pesantren An Nawawi. Pondok Pesantren An Nawawi berhasil menyelenggarakan pendidikan karakter dengan unsur unsur penunjang yaitu kemandirian kepemimpinan pesantren, peraturan pondok pesantren dan manajemen pengelolaan yang baik.

Keywords: pendidikan, karakter, Manajemen, pesantren

\section{PENDAHULUAN}

Faktor yang begitu menentukan dan berpengaruh pada perubahan sosial diantanya adalah Pendidikan.Dengan pendidikanlah para generasi penerus bisa mempunyai karakter yang kokoh dalam upaya menerima tongkat estafet meneruskan keberlangsungan kepemimpinan bangsa.Namun, banyak pihak menilai 
bahwapembentukan karakter yang sesuai dengan harapan para pendahulu pada siswa-siswa sekolah formal justru mulai sulit ditemukan. Banyak di antara mereka yang terlibat dalam kenakalan remaja diantaranya tawuran, narkoba dan sebagainya.Oleh karena itu para pendidik di tuntut untuk mencari pendidikan alternatif dalam mengembangkan pendidikan karakter tersebut.

Diantara lembaga pendidikan Islam yang masih exis dan merupakan subkultur masyarakat Indonesia adalah pesantren.Pesantren adalah salah satu institusi yang unik dengan ciri-ciri khas yang sangat kuat dan lekat.Peran yang diambil adalah upaya-upaya pencerdasan bangsa yang telah turun temurun tanpa henti. Pesantrenlah yang memberikan pendidikan pada masa-masa sulit, masa perjuangan melawan kolonial dan merupakan pusat studi yang tetap survive sampai masa kini. Tujuan pendidikan pesantren menurut Zamakhsyari Dhofier, bukanlah untuk mengejar kepentingan kekuasaan, uang dan keagungan duniawi, tetapi ditanamkan kepada mereka bahwa belajar adalah semata-mata kewajiban dan pengabdian kepada Tuhan. ${ }^{1}$ Oleh karena itu, sebagai salah satu lembaga pendidikan, pesantren juga mempunyai tanggung jawab yang tidak kecil dalam membentuk karakter para santri.

Ada banyak pesantren di Indonesia, baik tradisional maupun modern yang telah memberikan kontribusi bagi proses pencerdasan bangsa. Jumlah Pondok Pesantren di Indonesia pada tahun 2018 keseluruhan sebanyak 27.218 dan 13,446 adalah pondok salaf sementara jumlah pondok pesantren khalafiyah sebanyak 3,064 dan jumlah pondok pesantern kombinasi sebanyak $10,708^{2}$

Pondok Pesanten An Nawawi Berjan didirikan pada tahun 1870 M oleh KH. Zarkasyi dengan nama Mafatihul 'Ulum. Kemudian pada sekitar tahun 1960 berubah nama Pondok Pesantren menjadi "Maftahul Ulum" atas persetujuan pengasuh (KH. Nawawi).Pada tahun 1965, sewaktu kepemimpinan dilanjutkan oleh KH. Nawawi, bin KH. Shiddieq bin KH. Zarkasyi, nama pondok pesantren diganti dengan nama “

\footnotetext{
LP3ES, 1981).

${ }^{1}$ Zamakhsyari Dhofier, Tradisi Pesantren: Studi tentang Pandangan Hidup Kiyai, (Jakarta:

${ }^{2}$ http://pendis.kemenag.go.id/file/dokumen/bukusaku1102.pdf
} 
Roudlotut Thullab “ yang berarti Taman Pelajar atau Taman Siswa, dan kemudian pada tanggal 7 Januari 1996, bertepatan dengan tanggal 16 Sya'ban 1416 H, kembali diganti menjadi “ An - Nawawi ${ }^{3}$

Madrasah yang diselenggarakan oleh Pondok Pesantren An-Nawawi yaitu; Madrasah Diniyah 'Ulya Banin/ Banat An-Nawawi (3 tahun), Madrasah Diniyah Wustha Banin/ Banat An-Nawawi (3 tahun) dan Madrasah Diniyah Awwaliyyah Banin/ Banat An-Nawawi (1 tahun).

Selain mengelola pendidikan madrasah salaf Ponpes An Nawawi Berjan Purworejo juga menyelenggarakan pendidikan formal yaitu : Pendidikan Formal yang telah diselenggarakan, yaitu : Madrasah Tsanawiyah (MTs) An-Nawawi 01 Berjan, dibuka sejak Tahun Pelajaran 1995/1996., Madrasah Tsanawiyah (MTs) An-Nawawi 02 Salaman di Purwosari Salaman Magelang, dibuka sejak Tahun Pelajaran 2000/2001., Madrasah Tsanawiyah (MTs) An-Nawawi 03 Kebumen, Jl. Tentara Pelajar No. 60 Kebumen, dibuka sejak Tahun Pelajaran 2003/2004. Madrasah Tsanawiyah (MTs) An-Nawawi 04 Kaligesing, Purworejo, dibuka sejak Tahun Pelajaran 2009/2010.Madrasah Tsanawiyah (MTs) An-Nawawi 05 Sarwodadi, Gadingrejo, Kepil, Wonosobo dibuka sejak Tahun Pelajaran 2014/2015. Madrasah Aliyah An-Nawawi 01 Berjan, dibuka sejak Tahun Pelajaran 2000/2001, Program Madrasah Aliyah Keagamaan (MAK), dan Program Madrasah Aliyah Umum (MAU). Madrasah Aliyah An-Nawawi 02 Salaman, dibuka sejak tahun pelajaran 2004/2005, Program Madrasah Aliyah Umum (MAU). Madrasah Aliyah An-Nawawi 03 Kebumen, dibuka sejak tahun pelajaran 2005/2006, Program Madrasah Aliyah Umum (MAU). Sekolah Tinggi Agama Islam An-Nawawi (STAIAN) Purworejo, dibuka sejak Tahun Akademik 2001/2002, Fakultas Syari'ah, Program Studi Muamalah (Ekonomi Islam), Program Studi Perbankan Islam (dibuka sejan Tahun Akademik 2015/2016 dan Terakreditasi B oleh BAN-PT, Program Studi Manajemen Pendidikan islam dan Program Studi Akhwalus Shaksiyah (Hukum Keluarga Islam).

\footnotetext{
${ }^{3}$ https://www.annawawiberjan.or.id/p/blog-page_62.html
} 
Pondok pesantren An Nawawi telah mengalami perkembangan yang cukup pesat, dengan santri kurang lebih 3.500 orang, namun Pondok Pesantren An Nawawi Berjan Purworejo tetap mempertahankan cirinya sebagai sebuah pesantren salaf dengan terus berusah menyesuaikan dan mengkombinasi dengan sekolah formal sebagai upaya memaksimalkan proses pembentukan generasi yang terbaik.Dalam penelitian ini penulis ingin mengetahu sejauhmanakah pesantren An Nawawi melakukan Manajemen pendidikan karakter sehingga mampu membentuk karakter para santi dengan maksimal.

\section{METODE}

Penelitian ini mendasarkan kepada studi kepustakaan (library research).Library research adalah serangkaian kegiatan yang berkenaan dengan metode pengumpulan data pustaka, membaca dan mencatat serta mengolah bahan penelitiannya.Ia merupakan suatu penelitian yang memanfaatkan sumber perpustakaan untuk memperoleh data penelitiannya. ${ }^{4}$

Dalam penelitian ini, penulis menggunakan penelitian deskriptifkritis dengan lebih menekankan pada kekuatan analisis sumber-sumber dan data-data yang ada dengan mengandalkan teori-teori dan konsepkonsep yang ada untuk diinterpretasikan berdasarkan tulisan-tulisan yang mengarah kepada pembahasan. Sumber-sumber tersebut di dapat dari karya yang di tulis oleh intelektual dan ahli yang berkompeten tentang pendidikan diantara karya-karya tersebut adalah qonun pondok pesantren An Nawawi, Pendidikan Karakter KaryaDoni Koesoema Albertus, Prinsip-prinsip Manajemen Karya George R Terry dan lain lain.

Dalam penelitian ini, setelah data terkumpul maka data tersebut dianalisis menggunakan Metode Analisis Deskriptif yaitu usaha untuk mengumpulkan dan

\footnotetext{
${ }^{4}$ Mustika Zed, Metode Penelitian Kepustakaan (Jakarta: Yayasan Obor Nasional, 2004), hlm. $2-3$
} 
menyusun suatu data, kemudian dilakukan analisis terhadap data tersebut. ${ }^{5}$ Serta menggunakan metode Analisis Kritis yang mana Analisis Kritis adalah sebuah pandangan yang menyatakan peneliti bukanlah subyek yang bebas nilai ketika memandang penelitian. Analisis yang sifatnya kritis umumnya beranjak dari pandangan atau nilai-nilai tertentu yang diyakini oleh peneliti. Oleh karena itu, keberpihakan peneliti dan posisi peneliti atas suatu masalah sangat menentukan bagaimana teks/ data ditafsirkan ${ }^{6}$

\section{HASIL DAN PEMBAHASAN}

\section{Manajemen Pendidikan Islam}

\section{a. Pengertian Manajemen Pendidikan Islam.}

Dari segi bahasa manajemen berasal dari bahasa Inggris yang merupakan terjemahan langsung dari kata management yang berarti pengelolaan, ketata laksanaan, atau tata pimpinan.Sementara dalam kamus Inggris Indonesia karangan John M. Echols dan Hasan Shadily management berasal dari akar kata to manage yang berarti mengurus, mengatur, melaksanakan, mengelola, dan memperlakukan ${ }^{7}$.

Ramayulis menyatakan bahwa pengertian yang sama dengan hakikat manajemen adalah al-tadbir (pengaturan) ${ }^{8}$. Kata ini merupakan derivasi dari kata dabbara (mengatur) yang banyak terdapat dalam Al Qur'an seperti firman Allah SWT :
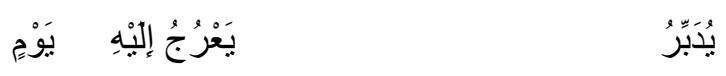

\footnotetext{
${ }^{5}$ WinarnoSurachman .Pengantar Penelitian Ilmiah: Dasar, Metode, Teknik (Bandung: Tarsita, 1990) Hal. 139

${ }^{6}$ Eriyanto, Analisis Wacana: Pengantar Analisis Teks Media, (Yogyakarta: LkiS, 2005)Cet. 5. hlm. 59

${ }^{7}$ John M. Echols\& Hasan Shadily, Kamus Inggris-Indonesia (Jakarta: Balai Pustaka, 1995), Hal. 372.

${ }^{8}$ Ramayulis, Ilmu Pendidikan Islam, (Jakarta:Kalam Mulia, 2008), Hal.362
} 
Artinya : Dia mengatur urusan dari langit ke bumi, kemudian (urusan) itu naik kepadanya dalam satu hari yang kadarnya adalah seribu tahun menurut perhitunganmu (Al Sajdah : 05).

Dari isi kandungan ayat di atas dapatlah diketahui bahwa Allah swt adalah pengatur alam (manager).Namun, karena manusia yang diciptakan Allah SWT telah dijadaikan sebagai khalifah di bumi, maka dia harus mengatur dan mengelola bumi dengan sebaik-baiknya sebagaimana Allah mengatur alam raya ini.

Sementara manajemen menurut istilah adalah proses mengkordinasikan aktifitas-aktifitas kerja sehingga dapat selesai secara efesien dan efektif dengan dan melalui orang lain ${ }^{9}$. Sedangkan Sondang $\mathrm{P}$ Siagian mengartikan manajemen sebagai kemampuan atau keterampilan untuk memperoleh suatu hasil dalam rangka mencapai tujuan melalui kegiatankegiatan orang lain ${ }^{10}$.

Bila kita perhatikan dari kedua pengertian manajemen di atas maka dapatlah disimpulkan bahwa manajemen merupkan sebuah proses pemanfaatan semua sumber daya melalui bantuan orang lain dan bekerjasama dengannya, agar tujuan bersama bisa dicapai secara efektif, efesien, dan produktip. Sedangkan Pendidikan Islam merupakan proses transinternalisasi nilai-nilai Islam kepada peserta didik sebagai bekal untuk mencapai kebahagiaan dan kesejahteraan di dunia dan di akhirat.

Dengan demikian maka yang disebut dengan manajemen pendidikan Islam sebagaimana dinyatakan Ramayulis adalah proses pemanfaatan semua sumber daya yang dimiliki (ummat Islam, lembaga pendidikan atau lainnya) baik perangkat keras maupun lunak. Pemanfaatan tersebut dilakukan melalui

\footnotetext{
${ }^{9}$ Robbin dan Coulter, Manajemen (edisi kedelapan), (Jakarta:PT Indeks, 2007), Hal. 8.

${ }^{10}$ Sondang P Siagian, Filsafah Administrasi, (Jakarta: CV Masaagung, 1990), Hal.5.
} 
kerjasama dengan orang lain secara efektif, efisien, dan produktif untuk mencapai kebahagiaan dan kesejahteraan baik di dunia maupun di akhirat ${ }^{11}$.

\section{b. Fungsi-fungsi Manajemen Pendidikan Islam}

Henry Fayol seorang industriyawan Prancis, dia mengatakan bahwa fungsi-fungsi manajemn itu adalah merancang, mengorganisasikan, memerintah, mengoordinasi, dan mengendalikan.Gagasan Fayol itu kemudian mulai digunakan sebagai kerangka kerja buku ajar ilmu manajemen pada pertengahan tahun 1950, dan terus berlangsung hingga sekarang.

Sementara itu Robbin dan Coulter mengatakan bahwa fungsi dasar manajemen yang paling penting adalah merencanakan, mengorganisasi, memimpin, dan mengendalikan ${ }^{12}$. Sebagaimana itu Mahdi bin Ibrahim menyatakan bahwa fungsi manajemen atau tugas kepemimpinan dalam pelaksanaannya meliputi berbagai hal, yaitu : Perencanaan, pengorganisasian, pengarahan dan pengawasan ${ }^{13}$.

Uraian fungsi manajemen pendidikan Islam sesuai dengan pendapat yang dikemukan oleh Robbin dan Coulter yang pendapatnya senada dengan Mahdi bin Ibrahim yaitu : Perencanaan, pengorganisasian, pengarahan/kepemimpinan, dan pengawasan sebagai berikut:

1) Perencanaan (Planning)

Perencanaan adalah sebuah proses perdana ketika hendak melakukan pekerjaan baik dalam bentuk pemikiran maupun kerangka kerja agar tujuan yang hendak dicapai mendapatkan hasil yang optimal. Demikian pula halnya dalam pendidikan Islam perencanaan harus dijadikan langkah pertama yang benar-benar diperhatikan oleh para manajer dan para pengelola pendidikan Islam. Bahkan Allah

\footnotetext{
${ }^{11}$ Ramayulis, Ilmu,, Hal. 260.

${ }^{12}$ Robbin dan Coulter, Manajemen, Hal. 9.

${ }^{13}$ Mahdi bin Ibrahim, Amanah dalam Manajemen, (Jakarta: Pustaka Al Kautsar, 1997), Hal. 61.
} 
memberikan arahan kepada setiap orang yang beriman untuk mendesain sebuah rencana apa yang akan dilakukan dikemudian hari, sebagaimana Firman-Nya dalam Al Qur'an Surat Al Hasyr : 18 yang berbunyi :
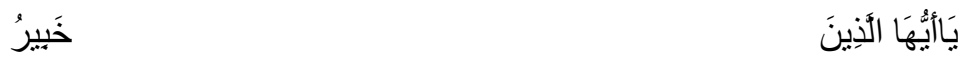

Artinya: Hai orang-orang yang beriman, bertakwalah kepada Allah dan hendaklah Setiap diri memperhatikan apa yang telah diperbuatnya untuk hari esok (akhirat); dan bertakwalah kepada Allah, Sesungguhnya Allah Maha mengetahui apa yang kamu kerjakan.

Ketika menyusun sebuah perencanaan dalam pendidikan Islam tidaklah dilakukan hanya untuk mencapai tujuan dunia semata, tapi harus jauh lebih dari itu melampaui batas-batas target kehidupan duniawi. Arahkanlah perencanaan itu juga untuk mencapai target kebahagiaan dunia dan akhirat, sehingga kedua-duanya bisa dicapai secara seimbang.

Manajemen pendidikan Islam dalam hal perencanaan menurut Ramayulis meliputi :

a) Penentuan prioritas agar pelaksanaan pendidikan berjalan efektif, prioritas kebutuhan agar melibatkan seluruh komponen yang terlibat dalam proses pendidikan, masyarakat dan bahkan murid.

b) Penetapan tujuan sebagai garis pengarahan dan sebagai evaluasi terhadap pelaksanaan dan hasil pendidikan

c) Formulasi prosedur sebagai tahap-tahap rencana tindakan.

d) Penyerahan tanggung jawab kepada individu dan kelompokkelompok kerja ${ }^{14}$.

Dari uraian di atas dapat diambil kesimpulan bahwa dalam Manajeman Pendidikan Islam perencanaan merupakan kunci utama untuk menentukan aktivitas berikutnya. Tanpa perencanaan yang

\footnotetext{
${ }^{14}$ Ramayulis, Ilmu, hal. 271.
} 
matang aktivitas lainnya tidaklah akan berjalan dengan baik bahkan mungkin akan gagal. Oleh karena itu buatlah perencanaan sematang mungkin agar menemui kesuksesan yang memuaskan.

2) Pengorganisasian (organizing)

Pengorganisasian menurut Terry pengorganisasian merupakan kegiatan dasar dari manajemen dilaksnakan untuk mengatur seluruh sumber-sumber yang dibutuhkan termasuk unsur manusia, sehingga pekerjaan dapat diselesaikan dengan sukses ${ }^{15}$.

Organisasi dalam pandangan Islam bukan semata-mata wadah, melainkan lebih menekankan pada bagaimana sebuah pekerjaan dilakukan secara rapi.Organisasi lebih menekankan pada pengaturan mekanisme kerja.Dalam sebuah organisasi tentu ada pemimpin dan bawahan. $^{16}$

Ramayulis menyatakan bahwa pengorganisasian dalam pendidikan Islam adalah proses penentuan struktur, aktivitas, interkasi, koordinasi, desain struktur, wewenang, tugas secara transparan, dan jelas. Dalam lembaga pendidikan Islam, baik yang bersifat individual, kelompok, maupun kelembagaan. Sebuah organisasi dalam manajemen pendidikan Islam akan dapat berjalan dengan lancar dan sesuai dengan tujuan jika konsisten dengan prinsip-prinsip yang mendesain perjalanan organisasi yaitu Kebebasan, keadilan, dan musyawarah. ${ }^{17}$

Dari uraian di atas dapat difahami bahwa pengorganisasian merupakan fase kedua setelah perencanaan yang telah dibuat sebelumnya.Pengorganisasian terjadi karena pekerjaan yang perlu dilaksanakan itu terlalu berat untuk ditangani oleh satu orang

\footnotetext{
${ }^{15}$ George R Terry, Prinsip-prinsip Manajemen, (Jakarta: Bumi Aksara, 2006), Hal. 73.

${ }^{16}$ Didin Hafidudin dan Hendri Tanjung, Manajemen Syariah dalam Prkatik, (Jakarta: Gema Insani, 2003), Hal. 101.

${ }^{17}$ Ramayulis, Ilmu, hal. 272.
} 
saja.Dengan demikian diperlukan tenaga-tenaga bantuan dan terbentuklah suatu kelompok kerja yang efektif.

3) Pengarahan (directing).

Pengarahan adalah proses memberikan bimbingan kepada rekan kerja sehingga mereka menjadi pegawai yang berpengetahuan dan akan bekerja efektif menuju sasaran yang telah ditetapkan sebelumnya.

Terdapat empat komponen dalam pengarahan, yaitu pengarah, yang diberi pengarahan, isi pengarahan, dan metode pengarahan.Pengarah adalah orang yang memberikan pengarahan berupa perintah, larangan, dan bimbingan.Yang diberipengarahan adalah orang yang diinginkan dapat merealisasikan pengarahan.Isi pengarahan adalah sesuatu yang disampaikan pengarah baik berupa perintah, larangan, maupun bimbingan.Sedangkan metode pengarahan adalah sistem komunikasi antara pengarah dan yang diberi pengarahan.

Dalam manajemen pendidikan Islam, agar isi pengarahan yang diberikan kepada orang yang diberi pengarahan dapat dilaksanakan dengan baik maka seorang pengarah setidaknya harus memperhatikan beberapa prinsip berikut, yaitu : Keteladanan, konsistensi, keterbukaan, kelembutan, dan kebijakan. Isi pengarahan baik yang berupa perintah, larangan, maupun bimbingan hendaknya tidak memberatkan dan diluar kemampuan sipenerima arahan.

Dengan demikian dapatlah disimpulkan bahwa fungsi pengarahan dalam manajemen pendidikan Islam adalah proses bimbingan yang didasari prinsip-prinsip religius kepada rekan kerja, sehingga orang tersebut mau melaksanakan tugasnya dengan sungguhsungguh dan bersemangat disertai keikhlasan yang sangat mendalam.

4) Pengawasan (Controlling)

Pengawasan adalah keseluruhan upaya pengamatan pelaksanaan kegiatan operasional guna menjamin bahwa kegiatan tersebut sesuai 
dengan rencana yang telah ditetapkan sebelumnya.Bahkan Didin dan Hendri (2003:156) menyatakan bahwa dalam pandangan Islam pengawasan dilakukan untuk meluruskan yang tidak lurus, mengoreksi yang salah dan membenarkan yang hak.

Menurut Ramayulis pengawasan dalam pendidikan Islam mempunyai karakteristik sebagai berikut: pengawasan bersifat material dan spiritual, monitoring bukan hanya manajer, tetapi juga Allah Swt, menggunakan metode yang manusiawi yang menjunjung martabat manusia. Dengan karakterisrik tersebut dapat dipahami bahwa pelaksana berbagai perencaan yang telah disepakati akan bertanggung jawab kepada manajernya dan Allah sebagai pengawas yang Maha Mengetahui. Di sisi lain pengawasan dalam konsep Islam lebih mengutamakan menggunakan pendekatan manusiawi, pendekatan yang dijiwai oleh nilai-nilai keislaman ${ }^{18}$.

\section{Pendidikan Karakter}

Secara harfiah, karakter berarti kualitas mental atau moral, kekuatan moral, nama atau reputasinya. Dalam pandangan Doni Koesoema karakter diasosiasikan dengan temperamen yang memberinya sebuah definisi yang menekankan unsur psikososial yang dikaitkan dengan pendidikan dan konteks lingkungan.Karakter juga dipahami dari sudut pandang behavioral yang menekankan unsur somatopsikis yang dimiliki oleh individu sejak lahir. Di sini karakter dianggap sama dengan kepribadian. Kepribadian dianggap sebagai ciri atau karakteristik atau gaya atau sifat khas dari diri seseorang, yang bersumber dari bentukan-bentukan yang diterima dari lingkungannya, misalnya pengaruh keluarga pada masa kecil dan bawan seseorang sejak lahir. ${ }^{19}$

\footnotetext{
${ }^{18}$ Ramayulis, Ilmu, hal. 274.

${ }^{19}$ Doni Koesoema Albertus, Pendidikan Karakter; Strategi Mendidik Anak di Zaman Global, (Jakarta: Grasindo, 2010), h. 79-80. Baca juga: Sjarkawi, Pembentukan Kepribadian Anak; Peran Moral, Intelektual, Emosional dan Sosial sebagai Wujud Integritas Membangun Jatidiri, (Jakarta: Bumi Aksara, 2006), h. 11.
} 
Menurut Tadzkirotun Musfiroh karakter mengacu pada serangkaian sikap (attitude), perilaku (behaviors), motivasi (motivations) dan keterampilan (skills) Makna karakter itu sendiri sebenarnya berasal dari bahsa Yunani yang berarti to mark atau menandai dan memfokuskan pada aplikasi nilai kebaikan dalam bentuk tindakan atau tingkah laku, sehingga orang yang tidak jujur, kejam, rakus dan berperilaku jelek dikatakan sebagai orang yang berkarakter jelek. Sebaliknya orang yang berperilaku sesuai dengan kaidah moral dinamakan berkarakter mulia. $^{20}$

Dengan demikian, bisa dikatakan bahwa pendidikan karakter adalah sebuah sistem yang menanamkan nilai-nilai karakter pada peserta didik, yang mengandung komponen pengetahuan, kesadaran individu, tekad, serta adanya kemauan dan tindakan untuk melaksnakan nilai-nilai, baik terhadap Tuhan Yang Mahaesa, diri sendiri, sesama manusia, lingkungan, maupun bangsa sehingga akan terwujud insān kāmil. ${ }^{21}$

\section{Manajemen Pendidikan Karakter di Pondok Pesantren An Nawawi}

Pesantren merupakan sebuah komunitas sosial yang memiliki budaya yang khas.Kekhasan pesantren ini ditengarai beberapa hal, yaitu pertama, model kepemimpinan pesantren yang sangat mandiri tidak terstuktur oleh pemerintah.Kedua, bahan ajar berupa kitab-kitab rujukan yang dikaji berasal dari kitab-kitab klasik yang dikenal dengan sebutan kitab kuning dan yang terakhir adalah (value system) sistem nilai yang dipilih.

Pondok Pesantren An Nawawi Berjan Purworejo yang masih mengidentikkan dirinya sebagai pondok salafiyah menjadi fokus utama peneliti untuk menelisik eksistensi tiga komponen tersebut di atas, yang dianggap sebagai penopang kuat atas pendidikan karakter yang dikembangkan di pesantren.

\footnotetext{
${ }^{20}$ Nurla Isna Aunillah, Panduan Menerapkan Pendidikan Karakter di Sekolah, (Yogyakarta: Laksana, 2011), h. 19.

${ }^{21}$ Ibid., h. 18-19.
} 
Secara normatif-organisatoris, pimpinan Pondok Pesantren An Nawawi Berjan Purworejo dipegang oleh Pengasuh Pondok Pesantren yaitu KH. Achmad Chalwani. Adapun dalam menjalankan kegiatan sehari hari supaya dapat terlaksana dengan baik maka Pengasuh menunjuk santri senior sebagai pengurus pondok pesantren.

Setiap lembaga pendidikan baik salaf maupun formal pastilah mempunyai aturan yang dijadikan sebagai pegangan agar lembaga tersebut dapat berjalan dengan stabil, Sebagaimana lembaga pendidikan yang lain, Pondok pesantren An Nawawi juga mempunyai peratururan yang harus dipatuhi oleh peserta didik (santri) yang di sebut sebagai Qonun Pondok Pesantren, Adapun peraturan peraturan tersebut terbagi menjadi beberapa pasal yaitu:

a. Pasal Kewajiban

Kewajiban adalah peraturan yang harus di jalankan dan di patuhi oleh setiap santri, Kewajiban kewajiban tersebut yaitu : (1)Menjaga almamater pondok pesantren, (2) Mengikuti madrasah dengan segala peraturanya (3) Memtaati segala bentuk peraturan pondok Pesantren, kebijakan/dawuh (perintah) pengasuh dan kebijakan pengurus Pondok Pesantren, (4) Meminnta izin kepada pengasuh/ pengurus Pondok Pesantren apabila ingin keluar atau meninggalkan pondok Pesantren (5) Mengikuti berbagai jenis pengajian luar Madrasah sesuai dengan tingkatan masing-masing yang telah ditetapkan oleh madrasah baik berupa pengajian ba'da subuh, ba'da dhuhur, qira'ah, musyawarah dll, (6) Mengikuti kegiatan yang diadakan rutin setiap malam jum'at sesuai dengan jadwal, (6) Membiasakan hal-hal yang mendorong tercapainya ilmu nafi' (7) Sholat berjama'ah serta wiridan dengan imam rawatib/ penggantinya, (8) Membaca al-Qur'an setelah sesuai sholat maktubah, (10) Membayar administrasi Pondok pesantren dan Madrasah setiap bulanya sesuai dengan ketentuanya, (11) Berpakaina syar'an wa adaban (Keluar Pondok harus memakai Baju dan berpeci, tidak boleh memakai kaos dan lepas Peci, ketika olah raga atau jalan ngidul tidak boleh memakai celana 
pendek, tidak boleh duduk dimasjid dengan hanya memakai singlet, ketika sekolah harus rapi sesuai dengan ketentuan hari, dan baju dimasukan kerapian dari segala hal), (12) Melaksanakan jaga malam bergilir sesuai dengan jadwal, (13) Memakai baju lengan panjang ketika melaksanakan sholat maktubah, berbagai jenis kegiatan yang diadakan oleh Pondok Pesantren maupun himpunan, (14) Berkepribadian muslim, (15) Disiplin, terutama bagi santri yang double sekolah formal sesuai dengan peraturan dan ketentuanya masingmasing, (16) Melapor kepada pengurus Pondok Pesantren apabila menerima tamu, (16) Menghormati tamu terutama "alim Ulama dan pejabat pemerintah, (18) Mengikuti ro'an (kerja bakti) setiap kali diadakan, (19) Menghormati yang lebih tua dan menyayangi yang muda, (20) Bergaul dengan cara yang baik, (21) Ziarah makam muassis pada jumat pagi ${ }^{22}$

b. Pasal Larangan

Larangan adalah peraturan yang mengatur hal hal yang harus di tinggalkan oleh setiap santri, pasal larangan ini terbagi atas beberapa tingkatan yaitu:

1) Larangan Berat

(1) Terlibat perzinahan; (2) Berpacaran; (3) Memalsukan tanda tangan pengasuh, kepala, pengurus, mustahiq, dan ustadz Pondok Pesantren; (4) Bersikap tidak sopan/ melawan ustadz, dan atau pengurus; (5) Keluar Pondok Pesantren tanpa izin; (6) Mencuri; (7) Ghosob; (8) Membawa, meminjamkan, menyewa sepeda motor atau mobil, hand phone (HP), MP3, MP4, dan sejenisnya; (9) Berjudi dengan alat dan cara apapun dan dimanapun; (10) Membawa/ terlibat minuman keras/ obat terlarang; (11) Berkelahi; (12) Menonton hiburan yang tidak diselenggarakan Pondok Pesantren/ tanpa arahan pengasuh; (13) Merusak sarana/prasarana Pondok Pesantren; (14) Melakukan aktifitas bisnis; (15) Tidak melaksanakan

\footnotetext{
${ }^{22}$ https://www.annawawiberjan.or.id/p/tata-tertib-qonun-pondok-pesantren_67.html
} 
tugas jaga dan piket Pondok Pesantren; (16) Mewarnai rambut/ semiran; (17) Membolos baik kegiatan Pondok Pesantren ataupun formal; (18) Mencemarkan nama baik Pondok Pesantren; (19) Mandi dikali dengan telanjang; (20) Membuat tulisan atau memposting sesuatu yang tidak sopan dalam akun media sosial.

2) Larangan Sedang

(1) Berkorespondensi/ membawa surat/ foto/ sesuatu lain yang berkaitan dengan lawan jenis; (1) Membawa/ menyebarkan tulisan yang dapat menimbulkan keresahan, termasuk membawa/ membaca/ melihat buku, film/ media porno lainya; (3) Mengikuti organisasi terlarang ataukumpulan anak nakal; (4) Memakai pakaian yang tidak syar'an wa adaban; (5) Merokok bagi siswa MTs; (6) Keluar masuk Pondok Pesantren/ madrasah melalui jalan tidak resmi; (7) Tidak melaksanakan sholat maktubah dengan berjamaah; (8) Tidak mengikuti ziarah kemakam masyayikh setiap jum'at pagi; (9) Mengendong/ berada di kamar lain tanpa mendapat izin dari ketua kamar; (10) Mengendong di rumah penduduk; (11) Mengganggu atau mengacau kelas pada waktu pelajaran atau jam kosong; (12) Duduk/ tongkrongan di pinggir jalan, mengganggu kenyamanan pengguna jalan; (13) Mengadakan pungutan liar (pungli); (14) Bermain, berolah raga dan sejenisnya yang tidak sesuai dengan jadwal Pondok Pesantren; (15) Merokok dalam keadaan masih berseragam sekolah.

\section{3) Larangan Ringan}

(1) Menghasut santri lain yang dapat menimbulkan keresahan; (2) Memiliki dan menyimpan senjata tajam yang membahayakan; (3) Melindungi dan membela teman yang berbuat salah; (4) Terlambat membayar administrasi Pondok Pesantren; (5) Memakai gelang atau kalung, anting-anting, berkuku panjang, dan berambut gondrong; (6) Tidak mengikuti kegitan malam jum'at sesuai dengan jadwal yang telah 
di tentukan; (7) Berseragam tidak sesuai dengan ketentuan baik madrasah ataupun formal; (8) Makan/ jajan di lingkungan/ warung yang dilarang oleh Pondok Pesantren; (9) Makan/ minum sambil berjalan/ berdiri; (10) Bercanda ketika sholat berjama'ah/ wiridan sedang berlangsung; (11) Meninggalkan tempat sholat sebelum wiridan selesai; (12) Tidak melapor ketika menerima tamu; (13) Tidak mengikuti ro'an (kerja bakti); (14) Tidur pada saat jaga malam. ${ }^{23}$

c. Pasal Anjuran

(1) Dawaamul wudlu (melanggengkan wudlu/ selalu dalam keadaaan suci);

(2) Melaksanakan sholat dluha, sholat tahajut, puasa sunat dan ibadah-ibadah sunat lainya; (3) Memperbanyak berziarah ke-makam Muassis; (4) Berjalan maksimal dua-dua ketika sekolah/ madrasah/ melewati ndalem pengasuh; (5) Hidup hemat/ menabung. ${ }^{24}$

d. Pasal Hukuman

1) Hukuman Berat

(1) Barang bukti disita; (2) Direndam 1 jam; (3) Digundul; (4) Digundul dan dikembalikan pada orang tua

2) Hukuman Sedang

(1) Barang bukti disita; (2) Direndam selama 1 jam; (3) Bersih-bersih; (4) Membaca a-Qur'an

3) Hukuman Ringan

(1)Barang bukti disita; (2) Diperingatkan; (3) Membaca al-Qur' an ${ }^{25}$

e. Pasal Tambahan

Hal-hal lain yang belum termasuk dalam tata tertib (qonun) ini akan di sampaikan kemudian sesuai dengan kebijakan Pondok Pesantren ${ }^{26}$

\footnotetext{
${ }^{23} \mathrm{Ibid}$

${ }^{24}$ Ibid

${ }^{25}$ Ibid

${ }^{26}$ Ibid
} 
Peraturan Peraturan tersebut dalam rangka supaya Seluruh rangkaian kegiatan santri di pondok ini dapat terlaksana dengan baik, disamping itu semua peraturan dibuat sebagai upaya pembentukan karakter yang baik pada santri dengan senantiasa membiasakan diri dengan perilaku perilaku yang terpuji dalam hubungan dengan Allah Swt, sesama manusia dan dengan lingkungan.

Pasal kewajiban sebagaimana yang telah terpapar di atas, dapat kita ketahui bahwasanya pembentukan karakter pada santri oleh pondok pesantren begitu serius di jalankan.Pembentukan karakter positif yang ada di Pesantren seperti yang tertuang di dalam pasal kewajiban, melahirkan budaya-budaya yang sangat dibutuhkan bagi upaya peningkatan peran santri di tengah-tengah pergaulan sosialnya. Pasal kewajiban menumbuhkan kebiasaan agung seperti kebiasaan kejujuran, kebiasaan disiplin, kebiasaan kreatif dan mandiri, kebiasaan bersih serta kebiasaan peduli terhadap lingkungan memperkuat metode pendidikan karakter pada santri yang nantinya akan terbentuk dengan baik. Dari itu, Podok pesantren An Nawawi dalam upaya membentuk karakter santri melalui manajemen yang jelas dan terukur dengan perencanaan yang baik, Pengorganisasian yang baik, kontrol yang baik dan pengawasan yang baik pula.Dengan begitu, membangun karakter santri secara otomatis menciptakan kebiasaan yang sangat dibutuhkan oleh komunitas itu sendiri.Dalam waktu bersamaan juga, terciptanya kebiasaan turut pula menebalkan karakter yang terpancang dalam ranah mental santri sehingga ini menjadi ukuran-ukuran moral dalam melakukan tindakannya kelak di masyarakat.

Pasal Larangan mengatur para santri agar senantiasa berlaku disiplin dengan meninggalkan hal hal yang dilarang pondok pesantren.Dengan peraturan ini para santri dapat membedakan mana yang baik dan mana yang tidak baik.Hal yang baik untuk dilaksanakan dan hal yang tidak baik untuk di tinggalkan. Pasa larangan ini membiasakan santri untuk senantiasa menjaga dirinya agar terhindar dari ha hal yang di larang sehingga membentuk karakter santri yang telah 
terbiasa menghindari sesuatu yang dilarang baik oleh agama maupun oleh negara dimasa mendatang.

Pasal Anjuran memberikan pendidikan kepada para santri mengenai suatu alternatif kebaikan yang seharusnya dilaksanakan.Dengan pasal anjuran ini mengajarkan para santi untuk senantiasa memilih alternatif kebaikan sehingga kedepan membuat santri terbiasa melakukannya. Alternatif kebaikan yang di anjrkan misalnya Dawaamul wudlu (melanggengkan wudlu/ selalu dalam keadaaan suci) ini mengajarkan pada santri untuk membiasakan menjalankan ibadah walaupun itu kelihatannya kecil, Anjuran Melaksanakan sholat dluha, sholat tahajut, puasa sunat dan ibadah-ibadah sunat lainya juga mengajarkan para santi untuk senantiasa tekun dalam beribadah bukan hanya yang wajib saja tapi juga yang sunnah. Anjuran memperbanyak berziarah ke-makam Muassis mengajarkan para santri untuk senantiasa mengingat para pendahulu dan meneladaninya serta mengingat akan sejatinya hidup yang bukan hanya dunia saja tapi juga akhirat. Berjalan maksimal dua-dua ketika sekolah/ madrasah/ melewati ndalem pengasuh mengajarkan para santri untuk terbiasa bertoleransi dan menghormati orang lain dengan memberikan kesempatan orang lain menggunakan fasilitas umum secara bersama sama. Hidup hemat/ menabung mengajarkan dan membiasakan santri untuk hidup sederhana dan tidak boros dalam menggunakan bekalnya karena hidup bukan hanya saat ini saja namun masih ada hari esok dan nanti sehingga dengan menabung bisa untuk memenuhi kebutuhan dimasa yang akan datang.

Pasal Hukuman sebagai upaya melatih para santi untuk bertanggung jawab atas segala perbuatan yang telah dibuatnya sehingga dengan peraturan ini membentuk karaktersantri menjadi manusia yang pemberani dan tidak pengecut dimasa mendatang.

Pondok Pesantren An Nawawi telah berhasil memanajemen pendidikan karakter dengan indikasi yang bisa digunakan sebagai parameter keberhasilan pendidikan karakter adalah mematuhi aturan-aturan sosial yang berlaku dalam 
lingkungan yang lebih luas. Kebiasaan mematuhi aturan dan tata tertib telah ditanamkan pada santri sejak mereka mulai masuk ke Pesantren.Dalam aturan itu, terdapat kewajiban-kewajiban yang harus dipenuhi.Laranganlarangan pun juga tertulis secara jelas, sehingga hal ini juga harus dijauhi, jangan sampai dilanggar.Berikutnya adalah sanksi-sanksi atas pelanggaran yang dilakukan oleh santri.Sebab, peraturan tanpa sanksi dianggap efektivitasnya sangat lemah.Kesadaran atas wujud aturan ini, sebenarnya, adalah sebagai usaha untuk memayungi kepentingan pondok dalam rangka mengemban tanggung jawabnya sebagai lembaga pendidikan yang bertujuan mulia.Aturan ini dibuat bukan semata-mata membatasi kemerdekaan santri, lebih pada usaha untuk melindungi kepentingan bersama serta mewujudkan ketenteraman bersama sehingga tujuan dan cita-cita santri bisa digapai secara maksimal.Bagi santri di dua pondok ini, peraturan santri merupakan "panglima" untuk menciptakan keteraturan dan kedisiplinan seluruh santri.Meski demikian, banyak juga santri yang berpikirnya melewati batas-batas aturan normatif yang ada.Artinya mereka sudah memiliki kesadaran tinggi serta menghayati dan mendalami budaya-budaya pesantren yang selalu hidup mengiringi aktivitasnya.Menurut mereka, aturan semacam ini hanyalah pantas diperuntukkan bagi mereka yang hati nuraninya belum bisa mengendalikan perilakunya. Dengan kesadaran seperti ini, akan memunculkan pentingnya makna substantif atas aturan normatif yang dibuat oleh mereka yang berwenang dalam batas pergaulan yang lebih luas.

Disamping hal di atas, indikasi pemanfaatan lingkungan secara bertanggung jawab menjadi hal yang dapat digunakan sebagai indikator keberhasilan pelaksanaan pendidikan karakter di pondok ini. Selain itu, pembiasaan hidup bersih, sehat, bugar, aman dan memanfaatkan waktu luang juga menjadi indikasi berjalannya proses pendidikan ini. Tidak itu saja, bahkan, kemampuan santri berkomunikasi dan berinteraksi secara efektif dan santun juga menjadi penguat hadirnya pendidikan karakter di pesantren ini. Kalau indikatorindikator di atas dijadikan pijakan berpikir untuk menentukan tingkat 
keberhasilan pendidikan karakter di Pesantren An Nawawi, maka pendidikan tersebut bisa dikatakan cukup berhasil dan perlu dikembangkan dalam tingkat yang lebih luas lagi.

Keberhasilan ini menurut peneliti disebabkan ada beberapa faktor, yaitu keteladan dari Kiai.Kemudian intensitas interaksi yang terjalin antara santri dengan santri, antara santri dan pengurus, serta antara santri, pengurus dan pengasuh.Terakhir adalah aturan main yang ditaati bersama, yang tertulis dalam Peraturan Santri yang di tanda tangani oleh Pengasuh. Ketiga hal inilah yang menyebabkan pendidikan karakter di pesantren An Nawawi ini bisa terbangun pada diri santri secara kuat dan efektif.

Oleh sebab itu, jika dilihat dari proses keberhasilan pendidikan karakter, keteladan kiai di tengah komunitas pesantren tentu berakibat pada penanaman figur ideal yang patut ditiru dan dicontoh serta manajemen serta tata kelola pondok pesantren tersebut. Sehingga berlanjut pada proses hubungan timbal balik yang intensif di antara seluruh unsur pondok baik antara santri dengan santri, ataupun santri dengan pengasuh. Hubungan ini menimbulkan komunikasi timbal balik di antara mereka yang terlibat.Satu sisi Pengasuh menasihati dan membimbing, santri mengikutinya sebagai bentuk ketaatan pada sosok yang dikagumi.Selain itu, agar pelaksanaan seluruh aktivitas pondok berjalan sebagaimana yang diharapkan oleh pengasuh, maka perlu aturan santri ditegakkan. Dengan begitu proses penanaman karakter yang disinari oleh ajaranajaran kitab yang dipelajari serta teladan dari Kiai bisa dijalankan secara gradual, sistematis dan efektif oleh para santri.

\section{KESIMPULAN}

Hasil penelitian dapat disimpulkan bahwa :

1. Pesantren sebagai subkultur mempunyai tiga komponen inti, yaitu kepemimpinan kiai yang mandiri, tidak terstruktur dengan pemerintah, kemudian, Buku Ajar rujukan pengajian berasal dari kitab-kitab klasik dan terakhir mempunyai 
valuesystem tertentu yang dikembangkan dari kajian-kajiannya terhadap kitabkitab klasik atau lebih dikenal dengan kitab kuning. Komponen tersebut bergerak seiring dengan Manajemen yang baik hingga membentuk karakter sendiri. Pondok Pesantren An Nawawi Berjan Purworejo berhasil menjalankan misinya sebagai lembaga pendidikan Islam yang bidang garapannya bukan hanya mencerdaskan namun juga membetuk karakter positif.

2. Pendidkan karakter di Pondok pesantren ini di laksanakan dengan metode pembiasaan melaui peraturan Pondok Pesantren yang disebut Qonun Pondok Pesantren. Peraturan Pondok pesantren terdiri dari beberapa pasal yaitu pasal kewajiban, pasal larangan, pasal anjuran, pasal hukuman dan pasal tambahan.

3. Peraturan pondok pesantren terlaksana dengan memanfaatkan manajemen modern yaitu adanya Perencanaan, pengorganisasian, pengarahan dan pengawasan secara berkesinambungan karena keberadaan lokasinya menjadi satu sehingga terjadi hubungan yang intensif antara Santri, Kyai dan Pengurus. Hal inilah yang kemudian membuat peraturan yang ada menjadi kebiasan sehari hari dan membentuk karakter yang baik bagi para santri.

\section{DAFTAR PUSTAKA}

Albertus, Doni Koesoema, 2010, Pendidikan Karakter; Strategi Mendidik Anak di Zaman Global, Jakarta: Grasindo

Aunillah, Nurla Isna, 2011, Panduan Menerapkan Pendidikan Karakter di Sekolah, Yogyakarta: Laksana

Dhofier, Zamakhsyari, 1981, Tradisi Pesantren: Studi tentang Pandangan Hidup Kiyai, Jakarta: LP3ES.

Echols,John M. \& Hasan Shadily, 1995, Kamus Inggris-Indonesia Jakarta: Balai Pustaka

Eriyanto, 2005, Analisis Wacana: Pengantar Analisis Teks Media Cet. 5, Yogyakarta: LkiS. 
Hafidudin, Didin dan Hendri Tanjung, 2003, Manajemen Syariah dalam Prkatik, Jakarta: Gema Insani

Ibrahim, Mahdi bin, 1997, Amanah dalam Manajemen, Jakarta: Pustaka Al Kautsar

Ramayulis, 2008, Ilmu Pendidikan Islam, Jakarta: Kalam Mulia

Robbin dan Coulter, 2007, Manajemen (edisi kedelapan), Jakarta: PT Indeks.

Siagian, Sondang P, 1990, Filsafah Administrasi, Jakarta: CV Masaagung

Sjarkawi, 2006, Pembentukan Kepribadian Anak; Peran Moral, Intelektual, Emosional dan Sosial sebagai Wujud Integritas Membangun Jatidiri, Jakarta: Bumi Aksara

Surachman, Winarno, 1990, Pengantar Penelitian Ilmiah: Dasar, Metode, Teknik, Bandung: Tarsita

Terry, George R, 2006, Prinsip-prinsip Manajemen, Jakarta: Bumi Aksara

Zed, Mustika, 2004, Metode Penelitian Kepustakaan, Jakarta: Yayasan Obor Nasional

http://pendis.kemenag.go.id/file/dokumen/bukusaku1102.pdf

https://www.annawawiberjan.or.id/p/blog-page_62.html

https://www.annawawiberjan.or.id/p/tata-tertib-qonun-pondok-pesantren_67.html 